\title{
Alcoholic extract of propolis in Nile tilapia post-larvae and fingerlings' diets: effects on production performance, body composition and intestinal histology
}

\author{
LILIAN D. DOS SANTOS ${ }^{1}$, IZABEL V. ZADINELO ${ }^{2}$, LILIAN C.R. DA SILVA ${ }^{1}$, ROGÉRIO L. ZILLI ${ }^{1}$, \\ MARCO ANTONIO B. BARREIROS ${ }^{1}$, MARLISE T. MAUERWERK ${ }^{1}$ and FÁBIO MEURER ${ }^{1}$ \\ ${ }^{1}$ Programa de Pós-Graduação em Aquicultura e Desenvolvimento Sustentável, Universidade Federal \\ do Paraná/UFPR, Setor Palotina, Rua Pioneiro, 2153, 85950-000 Palotina, PR, Brazil \\ ${ }^{2}$ Programa de Pós-Graduação em Zootecnia, Universidade Estadual do Oeste do Paraná, Campus Marechal \\ Cândido Rondon, Rua Pernambuco, 1777, 85960-000 Marechal Cândido Rondon, PR, Brazil
}

Manuscript received on March 23, 2018; accepted for publication on September 1, 2018

\begin{abstract}
How to cite: SANTOS LD, ZADINELO IV, SILVA LCR, ZILLI RL, BARREIROS MAB, MAUERWERK MT AND MEURER F. 2019. Alcoholic extract of propolis in Nile tilapia post-larvae and fingerlings' diets: effects on production performance, body composition and intestinal histology. An Acad Bras Cienc 91: e20180297. DOI.10.1590/00013765201920180297
\end{abstract}

\begin{abstract}
The aim of this study was to evaluate the production performance of Nile tilapia post-larvae and fingerlings fed with increasing levels of alcoholic extract of propolis into diets. In Experiment 1, 1800 post-larvae were distributed in 30 tanks, in a completely randomized design with five treatments composed by the inclusion of $0,1,2,3$ and $4 \mathrm{~g}$ of dry propolis $/ \mathrm{kg}$ of feed, and six replicates. In experiment 2,1600 fingerlings were distributed in the same system and designed as experiment 1 . No significant effect was observed between treatments, for final weight, total and standard length, survival, and intestinal villus height. However, the propolis extract inclusion of $1 \mathrm{~g} / \mathrm{kg}$ in Nile tilapia post-larvae and fingerlings' feed resulted in a better body condition factor and higher body protein deposition $(\mathrm{p}<0.05)$. The condition factor is an estimate for the future growth of the animals, possibly the fish treated with propolis extract will present better growth, survival and greater reproductive potential rates. The results of the present study demonstrate that alcoholic extract of propolis improves the nutritional condition of Nile tilapia post-larvae and fingerlings, potentially leading to increased productivity in subsequent stages, as well as leading to improvement in fingerlings muscle deposition.
\end{abstract}

Key words: growth promoters, natural compound, Oreochromis niloticus, sex reversal effectiveness.

\section{INTRODUCTION}

Nile tilapia farming in the early stages is one of the most important steps, as it will define the quality and development of the animal in subsequent phases (Marengoni and Wild 2014). In the initial stages, occur the greatest disease outbreaks due to the

Correspondence to: Lilian Dena dos Santos

E-mail: liliansantos@ufpr.br

ORCid: https://orcid.org/0000-0003-1637-1300 low resistance to possible pathogens because they are not adapted to the normal microbiota present in the environment. In light of the problems with diseases, the use of antibiotics as growth promoters was initiated, providing significant results on the production performance and on the animals' health (Gonzales et al. 2012).

Nonetheless, the uncontrolled use of antibiotics produced strains with resistance genes, reducing the efficacy of the products (Cyrino et al. 2010), 
besides causing environmental pollution. From this, the search for alternative growth promoters such as propolis is necessary, furthermore it is a biodegradable product of plant origin, does not promote bacterial resistance and has low acquisition cost (Abdel-Mohsein et al. 2014).

Propolis is a natural product which contains more than 300 chemical compounds. In general, it contains $50-60 \%$ resins and balms, 30-40\% waxes, $5-10 \%$ essential oils, 5\% pollen grains, and microelements such as aluminum, calcium, strontium, iron, copper, manganese and small amounts of vitamins B1, B2, B6, C and E. It is known for its antimicrobial, antioxidant, antiinflammatory, immunomodulatory, hypotensive, healing, anesthetic, anticancer and anticariogenic properties (Ferreira et al. 2017, Coelho et al. 2010).

Currently the use of propolis in the diet has demonstrated an efficient bacteriostatic and bactericidal activity as concerns to several genera of bacteria, but little research on fish production performance has been done, considering the animals' responses, related to some of these biological activities (Coelho et al. 2010).

The appropriate dietary supplementation with propolis improves growth, feed efficiency, immune response and the eel's centesimal composition (Anguilla japonica), suggesting the possibility of using propolis as an additive (Bae et al. 2012), and may also have positive effects for other fish species, such as the Nile tilapia.

The objective of this study was to evaluate the effects of increasing levels of alcoholic propolis extract inclusion in diets of Nile tilapia postlarvae and fingerlings on the production/growth performance, body composition and intestinal histology.

\section{MATERIALS AND METHODS}

ASSAY 1: EFFECT OF PROPOLIS EXTRACT ON NILE TILAPIA POST-LARVAE PERFORMANCE

The experiment was conducted at the Laboratory of Fish Production Systems at Federal University of Paraná in Palotina Sector (Brazil), for 30 days. A total of 1,800 Nile tilapia post-larvae obtained from eggs collected in the mouth, were distributed in a completely randomized design with five treatments and six replicates. The experimental unit was a 60 $\mathrm{L}$ aquarium containing 60 larvae. The aquariums were arranged in water recirculation system with central biofilter and in each tank, was installed aeration system with diffusers coupled to a radial compressor. The photoperiod used was a $12-\mathrm{h}$ light-dark cycle. The treatments were composed by the inclusion of the propolis extract in the feed, at concentrations of 0 (Control), 1, 2, 3 and $4 \mathrm{mg}$ of dry propolis/kg of diet.

The propolis used to prepare the extract was obtained from local beekeepers (Western region of Paraná, Brazil). To prepare the extract, $100 \mathrm{~g}$ of dry propolis were dissolved in 1L of cereal alcohol, which were stored in a dark place for 30 days. Subsequently, the alcoholic extract was filtered, bottled, and kept refrigerated.

The alcoholic extract of propolis from each treatment $(10,20,30$ and $40 \mathrm{ml} / \mathrm{kg}$ of feed) was dissolved in $100 \mathrm{~mL}$ of ethyl alcohol (the same as the hormone) and subsequently mixed with each feed. The meals were provided four times a day (9:00 am, 11:30 a.m., 2:00 p.m. and 5:00 p.m.), to apparent satiation.

The experimental feed used were isocaloric, isocalcitic, isophosphoric and isoprotein, with 38\% digestible protein and $3,700 \mathrm{kcal} / \mathrm{kg}$ of digestible energy (Table I). For producing the feeds, some ingredients (soybean meal, corn, fish's flour) were milled in hammer crusher with $0.5 \mathrm{~mm}$ sieve and later mixed. After homogenization, $60 \mathrm{mg}$ of the hormone $17-\alpha$-methyltestosterone/kg was added in each diet according to the procedure described by Popma and Green (1990).

The water temperature was checked daily in the morning and afternoon. The other parameters, $\mathrm{pH}$, dissolved oxygen and water conductivity were measured weekly. Oxygen was measured with a 
TABLE I

Chemical composition of the diet experimental (natural matter) of Nile tilapia post-larvae.

\begin{tabular}{|c|c|}
\hline Ingredients & $(\mathrm{g} / \mathrm{kg})$ \\
\hline Fish flour & 405.90 \\
\hline Soybean meal & 387.50 \\
\hline Corn & 102.30 \\
\hline Soy oil & 89.10 \\
\hline Mineral and vitamin supplement ${ }^{1}$ & 10.00 \\
\hline Common salt & 5.00 \\
\hline BHT (Butyl Hydroxytoluene) & 0.20 \\
\hline Total & $1,000.00$ \\
\hline Nutrients & $(\%)$ \\
\hline Digestible energy $(\mathrm{kcal} / \mathrm{kg})^{3}$ & $3,700.00$ \\
\hline Crude protein $(\%)^{2}$ & 42.83 \\
\hline Digestible protein $(\mathrm{kcal} / \mathrm{kg})^{3}$ & 38.60 \\
\hline Ether extract $(\%)^{2}$ & 17.07 \\
\hline Linoleic acid $(\%)^{2}$ & 5.33 \\
\hline Lysine $(\%)^{2}$ & 3.36 \\
\hline Calcium $(\%)^{2}$ & 2.91 \\
\hline Crude fiber $(\%)^{2}$ & 2.09 \\
\hline Methionine + Cystine $(\%)^{2}$ & 1.85 \\
\hline Disponible phosphorus $(\%)^{3}$ & 1.50 \\
\hline
\end{tabular}

${ }^{1}$ Minimum levels per kilogram of product: Vit. A, 500,000 UI; Vit. D3, 200,000 UI; Vit. E, 5,000 mg; Vit. K3, 1,000 mg; Vit. B1, 1,500 mg; Vit. B2, 1,500 mg; Vit. B6, 1,500 mg; Vit. B12, 4,000 mg; Folic acid, $500 \mathrm{mg}$; Pantotenato Ca, 4,000 mg; Vit. C, 15,000 mg; Biotin, $50 \mathrm{mg}$; Inositol, 10,000; Nicotinamide, 7,000; Coline, 40,000 mg; Co, $10 \mathrm{mg}$; Cu, $500 \mathrm{mg}$; Fe, 5,000mg; I, 50 mg; Mn, 1,500 mg; Se, 10 mg; Zn, 5,000 mg. ${ }^{2}$ Nutrition requirements based on NRC (2011) and Hayashi et al. (2002).

${ }^{3}$ According to Pezzato et al. (2002).

portable dissolved oxygen meter (Alfakit AT$\left.160^{\circledR}\right)$; $\mathrm{pH}$ was measured with a benchtop $\mathrm{pH}$ meter (Kasvi AI $03449^{\circledR}$ ), and the electrical conductivity was measured with a benchtop conductivity meter (Tecnopon NT-CVM ${ }^{\circledR}$ ). During the experimental period, the water temperature was maintained at $26.11 \pm 0.02^{\circ} \mathrm{C}$ in the morning and $27.03 \pm 0.50^{\circ} \mathrm{C}$ in the afternoon, $\mathrm{pH}: 7.99 \pm 0.02$, dissolved oxygen: $5.70 \pm 0.19 \mathrm{mg} / \mathrm{L}$ and the electrical conductivity at $50.56 \pm 1.13 \mu \mathrm{S} / \mathrm{cm}$.

At the end of the experimental period, all animals were euthanized in a solution of water and clove oil (Simões etal.2010) in concentrations of 100 $\mathrm{mg} / \mathrm{L}$ (approved by the Animal Ethics Committee Protocol n ${ }^{\circ}$ 06/2015, of the Federal University of Paraná) according to CONCEA (2018). All fish of each experimental unit were weighed (analytical balance) and measured individually (digital caliper) to determine the production parameters: final weight, total length, standard length, biomass, survival and body condition factor (Body weight/ body length $\left.{ }^{3} \mathrm{x} 100\right)$.

Ten fingerlings from each experimental unit were preserved in formalin for the analysis of sex reversal effectiveness, according to the methodology of Popma and Green (1990). Three other fish were randomly selected from each experimental unit to collect the hepatopancreas and anterior intestine, to determine the hepatosomatic index and for histological evaluation, respectively.

Histological evaluations were performed at the Laboratory of Histopathology at UFPR, Palotina Sector. Three fragments from middle intestine (from three fish) were used for experimental unit. The biological material was fixed in buffered formaldehyde and later preserved in $70 \%$ alcohol. They were then dehydrated in an ascending series of $70 \%$ to $100 \%$ alcohol, later diaphanized in xylol for 30 minutes, and included in paraffin, to obtain semiseriate histological sections. The microtomy was performed in order to obtain histological sections of $7 \mu \mathrm{m}$. The histological sections were stained with the hematoxylin-eosin (HE) method. The photodocumentation was performed in the photomicroscope Olympus BX50, in 10X objective lens, using a computerized image system (Image Pro Plus - Version 5.2-Media Cybernetics).

For the statistical analyses were tested the assumptions by performing the normality of the data, using the Shapiro-Wilk, and the homoscedasticity test (equality of variance) using the Levenne test. The results of productive performance, sex reversal effectiveness, and intestinal histology were submitted to analysis of variance and regression 
analysis using the software STATISTICA 7.0 (StatSoft. Inc. 2004).

ASSAY 2: EFFECT OF PROPOLIS EXTRACT ON NILE TILAPIA FINGERLINGS PERFORMANCE

The second experiment was conducted at the Laboratory of Production Systems of Fish of the Federal University of Paraná at Palotina Sector (Brazil) for a period of 45 days. Six hundred Nile tilapia fingerlings were used (Oreochromis niloticus), about 45 days old and weighing $1 \pm 0.05$ g. The fish were distributed in 30 plastic aquariums in a recirculating aquaculture system, in a completely randomized design with five treatments (inclusion of propolis extract: $0,1,2,3$ and $4 \mathrm{~g}$ of dry propolis per $\mathrm{kg}$ of feed) and six replicates.

Tanks had constant aeration by microporous stones attached to an air compressor. Daily siphoning was performed in the morning (7:00 am) and in the afternoon $(4: 30 \mathrm{pm})$ to remove feces and eventual feedings, removing about $20 \%$ of the water in the first week and $40 \%$ by the end of the experimental period. The internal cleaning of the aquariums walls was carried out weekly. A 12-h light/dark cycle was adopted.

The alcoholic extract of propolis preparation have already been described in the previous item of the material and methods.

To manufacture the experimental feed the formulation ingredients (Table II) were milled ( 0.5 $\mathrm{mm}$ ) and then mixed. To add the alcoholic extract of propolis in each treatment, it was dissolved in $100 \mathrm{~mL}$ of distilled water and later mixed with each feed, and this was pelleted in the granulometry appropriate to the size of the fingerlings. Three feedings per day $(8 \mathrm{~h} 00,12 \mathrm{~h} 00$ and $17 \mathrm{~h} 00)$ were carried out at a level of $8 \%$ of the live weight, with weekly re-adjustment of the amount of feed supplied.

Dissolved oxygen and water temperature were measured daily, while $\mathrm{pH}$, total ammonia, and nitrite were measured weekly. Dissolved oxygen
TABLE II

Chemical composition of the diet experimental (natural matter) of Nile tilapia fingerlings.

\begin{tabular}{|c|c|}
\hline Ingredients & $(\mathrm{g} / \mathrm{kg})$ \\
\hline Soybean meal & 708.40 \\
\hline Corn & 166.80 \\
\hline Soy oil & 49.80 \\
\hline Mineral and vitamin supplement ${ }^{1}$ & 40.00 \\
\hline Dicalcium phosphate & 27.70 \\
\hline Common salt & 5.00 \\
\hline Calcitic limestone & 2.20 \\
\hline BHT (Butyl Hydroxytoluene) & 0.10 \\
\hline Total & $1,000.00$ \\
\hline Nutrients & $(\%)$ \\
\hline Digestible energy $(\mathrm{kcal} / \mathrm{kg})^{3}$ & $3,000.00$ \\
\hline Crude protein $(\%)^{2}$ & 33.54 \\
\hline Digestible protein $(\mathrm{kcal} / \mathrm{kg})^{3}$ & 30.00 \\
\hline Ether extract $(\%)^{2}$ & 26.62 \\
\hline $\begin{array}{l}\text { Crude fiber }(\%)^{2} \\
\text { Linoleic acid }(\%)^{2}\end{array}$ & $\begin{array}{l}4.51 \\
3.52\end{array}$ \\
\hline Lysine $(\%)^{2}$ & 2.01 \\
\hline Calcium $(\%)^{2}$ & 1.00 \\
\hline Disponible phosphorus $(\%)^{3}$ & 0.97 \\
\hline Methionine + Cystine $(\%)^{2}$ & 0.96 \\
\hline
\end{tabular}

${ }^{1}$ Minimum levels per kilogram of product: Vit. A, 500,000 UI; Vit. D3, 200,000 UI; Vit. E, 5.000 mg; Vit. K3, 1,000 mg; Vit. B1, 1,500 mg; Vit. B2, 1,500 mg; Vit. B6, 1,500 mg; Vit. B12, 4,000 mg; Folic acid, $500 \mathrm{mg}$; Pantotenate Ca, 4,000 mg; Vit. C, $15.000 \mathrm{mg}$; Biotin, $50 \mathrm{mg}$; Inositol, 10,000; Nicotinamide, 7,000; Coline, $40.000 \mathrm{mg}$; Co, 10mg; Cu, $500 \mathrm{mg}$; Fe, 5,000mg; I, 50 mg; Mn, 1,500 mg; Se, 10 mg; Zn, 5,000 mg.

${ }^{2}$ Nutrition requirements based on NRC (2011) and Hayashi et al. (2002).

${ }^{3}$ According to Pezzato et al. (2002).

was measured with a portable dissolved oxygen meter (Alfakit AT-160®) and $\mathrm{pH}$ with a benchtop pH meter (Kasvi AI 03449®). Total ammonia was determined by the colorimetric method of indophenol and nitrite was determinate by the colorimetric method of the Griess reaction (APHA 2005). The absorbance readings were performed in a spectrophotometer Belphotonics SP2000UV ${ }^{\circledR}$. In this assay 2 , the water temperature was maintained at $26.8 \pm 1.1^{\circ} \mathrm{C}$; pH was $7.5 \pm 0.2$; dissolved oxygen in the water was $5.3 \pm 2.0 \mathrm{mg} / \mathrm{L}$; and the 
total ammonia concentration amounted to $0.04 \pm$ $0.02 \mathrm{mg} / \mathrm{L}$ and the nitrite to $0.05 \pm 0.10 \mathrm{mg} / \mathrm{L}$.

At the end of the experimental period, fish were euthanized in a solution of water and clove oil (Simões et al. 2010), according to CONCEA (2018), in concentrations of $100 \mathrm{mg} / \mathrm{L}$ (approved by the Animal Ethics Committee - Protocol $n^{\circ}$ 06/2015, of the Federal University of Paraná). All fingerlings of each experimental unit were weighed (analytical balance) and measured (digital caliper) individually to determine the production performance parameters: total weight, total length, standard length and condition factor. Three fish were randomly selected from each experimental unit to collect the hepatopancreas and intestine, to determine the hepatosomatic index and for histological evaluation, respectively.

Histological evaluations were performed at the Laboratory of Histopathology at UFPR, Palotina Sector and have already been described in the previous item of the material and methods.

The other fingerlings were stored in plastic bags and kept frozen in a freezer for further analysis of whole body chemical composition (moisture, crude protein, ether extract and mineral matter) according to the methodologies described by AOAC (1995).

For the statistical analyses were tested the assumptions by performing the normality of the data, using the Shapiro-Wilk, and the homoscedasticity test (equality of variance) using the Levenne test. The data obtained from production performance, body chemical composition and intestinal histology were submitted to analysis of variance and regression analysis. All statistical analyzes were carried out using the software STATISTICA 7.0 (StatSoft. Inc. 2004).

\section{RESULTS}

ASSAY 1: EFFECT OF PROPOLIS EXTRACT ON NILE TILAPIA POST-LARVAE PERFORMANCE

In this assay, there were no differences $(p>0.05)$ on the production performance parameters, namely final weight, total length, standard length, sex reversal effectiveness, biomass and survival of Nile tilapia during sex reversal stage fed with increasing levels of propolis extract (Table III). Futhermore, no effect ( $p>0.05$ ) of increasing levels of alcoholic extract of propolis in diets of Nile tilapia post-larvae on intestinal villus height was observed (Table III).

On the other hand, concerning to the body condition factor, the propolis extract resulted in improvement $(\mathrm{p}<0.05)$ and a quadratic effect $(p<0.05)$ was observed for Nile tilapia fingerlings (Figure 1) with a maximum point of $2.6 \mathrm{~g} / \mathrm{kg}$ of feed, which may indicate a certain action of growth promoter, or even improved fish nutritional condition from alcoholic extract of propolis.

ASSAY 2: EFFECT OF PROPOLIS EXTRACT ON NILE TILAPIA FINGERLINGS PERFORMANCE

For the Nile tilapia fingerlings was also not observed significant effect ( $p>0.05$ ) of increasing levels of alcoholic extract of propolis in diets on the parameters of production performance: final weight, total length, standard length, and hepatosomatic index (Table IV). At the same time, the propolis extract in diet resulted in higher values for condition factor $(\mathrm{p}<0.05)$ and caused a quadratic effect $(\mathrm{p}<0.05)$ on the body condition factor for the Nile tilapia fingerlings (Figure 2), with a maximum point of $2.4 \mathrm{~g} / \mathrm{kg}$ of feed.

The intestinal villi height of Nile tilapia fingerlings did not change $(p>0.05)$ with the supplementation of increasing levels of alcoholic extract of propolis in the diet. The whole-body ether extract, moisture and mineral matter (Table V) of Nile tilapia fingerlings submitted to diets containing increasing levels of propolis extract did not present significant differences between the treatments $(p>0.05)$. Meanwhile, alcoholic extract of propolis inclusion provided an increase $(p<0.05)$ in body protein content (Table V), having the highest value (maximum) in $2.7 \mathrm{~g}$ of dry propolis $/ \mathrm{kg}$. 
TABLE III

Parameters of production performance and intestinal villi height of Nile tilapia post-larvae fed with increasing levels of alcoholic extract of propolis in the diet.

\begin{tabular}{|c|c|c|c|c|c|c|}
\hline \multirow{2}{*}{ Parameters } & \multicolumn{5}{|c|}{ Levels of inclusion of dry propolis in the diet $(\mathrm{g} / \mathrm{kg})$} & \multirow{2}{*}{$\operatorname{SEM}^{1}$} \\
\hline & $\mathbf{0}$ & 1 & 2 & 3 & 4 & \\
\hline Final weight $(g)^{\text {ns }}$ & $0.44^{\mathrm{a}}$ & $0.42^{\mathrm{a}}$ & $0.44^{\mathrm{a}}$ & $0.40^{\mathrm{a}}$ & $0.43^{\mathrm{a}}$ & 0.007 \\
\hline Total length $(\mathrm{cm})^{\mathrm{ns}}$ & $2.90^{\mathrm{a}}$ & $2.82^{\mathrm{a}}$ & $2.86^{\mathrm{a}}$ & $2.79^{\mathrm{a}}$ & $2.87^{\mathrm{a}}$ & 0.019 \\
\hline Standard length $(\mathrm{cm})^{\mathrm{ns}}$ & $2.27^{\mathrm{a}}$ & $2.21^{\mathrm{a}}$ & $2.26^{\mathrm{a}}$ & $2.19^{\mathrm{a}}$ & $2.27^{\mathrm{a}}$ & 0.017 \\
\hline Body condition factor $*$ & $1.12^{\mathrm{a}}$ & $1.74^{\mathrm{b}}$ & $1.65^{\mathrm{b}}$ & $1.65^{\mathrm{b}}$ & $1.69^{\mathrm{b}}$ & 0.114 \\
\hline Intestinal villi height $(\mu \mathrm{m})^{\mathrm{ns}}$ & $14.0^{\mathrm{a}}$ & $12.77^{\mathrm{a}}$ & 13.50 & $12.74^{\mathrm{a}}$ & $13.26^{\mathrm{a}}$ & 0.236 \\
\hline Effectiveness of sex reversal $(\%)^{\text {ns }}$ & $97.0^{\mathrm{a}}$ & $98.0^{\mathrm{a}}$ & $97.5^{\mathrm{a}}$ & $96.5^{\mathrm{a}}$ & $97.0^{\mathrm{a}}$ & 0.254 \\
\hline Biomass $^{\text {ns }}$ & $13.25^{\mathrm{a}}$ & $13.77^{\mathrm{a}}$ & $12.31^{\mathrm{a}}$ & $13.03^{\mathrm{a}}$ & $12.81^{\mathrm{a}}$ & 0.241 \\
\hline Survival $(\%)^{\mathrm{ns}}$ & $57.0^{\mathrm{a}}$ & $55.0^{\mathrm{a}}$ & $44.0^{\mathrm{a}}$ & $53.0^{\mathrm{a}}$ & $45.0^{\mathrm{a}}$ & 2.819 \\
\hline
\end{tabular}

Means followed by different letters on the same line differ by Tukey's test $(\mathrm{p}<0.05)$.

${ }^{1}$ Standard error mean.

${ }^{\text {ns }}$ Not significant.

* Quadratic effect $\left(\mathrm{Y}=-0.0008 \mathrm{x}^{2} 0.0411 \mathrm{x}+1.20 ; \mathrm{R}^{2}=0.74\right)$.

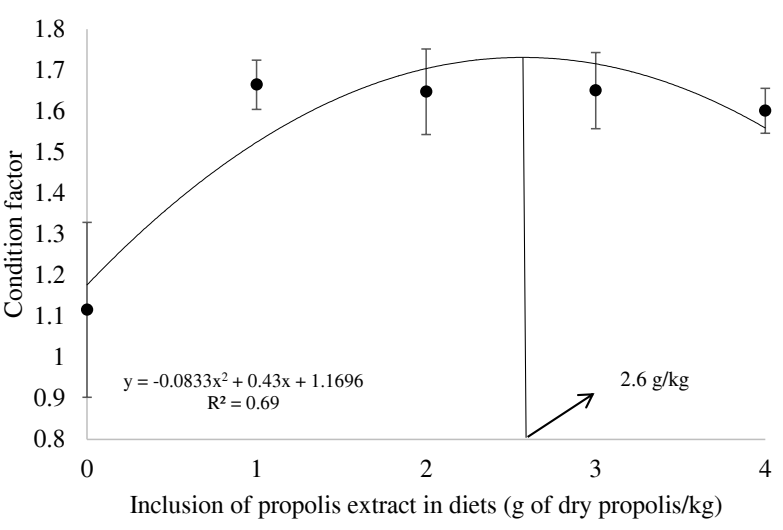

Figure 1 - Body condition factor of post-larvae of Nile tilapia fed with increasing levels of alcoholic extract of propolis.

\section{DISCUSSION}

The results show that alcoholic extract of propolis improved the condition factor of Nile tilapia postlarvae and fingerlings, although it had no effect on other production performance parameters. For common carp fingerlings (Cyprinus carpio) (Uczay et al. 2011), and Nile tilapia fingerlings (Santos et al. 2013) the alcoholic extract of propolis and residue from the processing of red propolis in diets, respectively, had no effect on any production performance parameter. However, for Nile tilapia fingerlings an improvement in productive

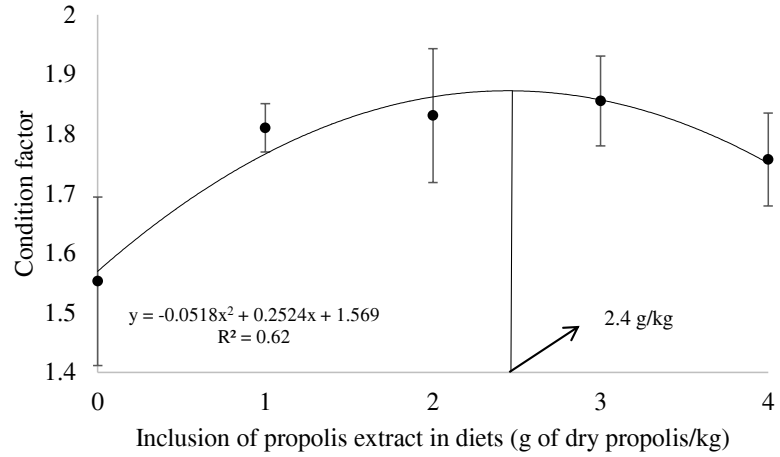

Figure 2 - Body condition factor of Nile tilapia fingerlings fed with increasing levels of alcoholic extract of propolis.

performance was observed with the addition of brown propolis extract to their diet (Meurer et al. 2009). For rainbow trout, a higher growth rate was also obtained when alcohol propolis extract was added to its diet (Deng et al. 2011). And, also, De La Cruz-Cervantes et al. (2018) concluded that propolis can improve fish growth, even at low doses.

On the other hand, Meurer et al. (2009) also found no effects of propolis added to the diet of Nile tilapia fingerlings for standard length and total length. The differences in the results may have been influenced by the propolis chemical 
TABLE IV

Parameters of production performance and intestinal villi height of Nile tilapia fingerlings fed with increasing levels of alcoholic extract of propolis in the diet.

\begin{tabular}{|c|c|c|c|c|c|c|}
\hline \multirow{2}{*}{ Parameter } & \multicolumn{5}{|c|}{ Inclusion levels of dry propolis in the diet $(\mathrm{g} / \mathrm{kg})$} & \multirow{2}{*}{ SEM } \\
\hline & $\mathbf{0}$ & 1 & 2 & 3 & 4 & \\
\hline Final weight $(\mathrm{g})^{\mathrm{ns}}$ & $7.69^{\mathrm{a}}$ & $7.76^{\mathrm{a}}$ & $8.72^{\mathrm{a}}$ & $8.33^{\mathrm{a}}$ & $9.20^{\mathrm{a}}$ & 0.287 \\
\hline Total length $(\mathrm{cm})^{\mathrm{ns}}$ & $8.36^{\mathrm{a}}$ & $7.44^{\mathrm{a}}$ & $7.75^{\mathrm{a}}$ & $7.64^{\mathrm{a}}$ & $8.18^{\mathrm{a}}$ & 0.172 \\
\hline Standard length $(\mathrm{cm})^{\mathrm{ns}}$ & $5.89^{\mathrm{a}}$ & $5.86^{\mathrm{a}}$ & $6.15^{\mathrm{a}}$ & $6.07^{\mathrm{a}}$ & $6.46^{\mathrm{a}}$ & 0.108 \\
\hline Hepatosomatic index ${ }^{\text {ns }}$ & $2.12^{\mathrm{a}}$ & $2.37^{\mathrm{a}}$ & $2.09^{\mathrm{a}}$ & $2.36^{\mathrm{a}}$ & $1.91^{\mathrm{a}}$ & 0.087 \\
\hline Body condition factor * & $1.54^{\mathrm{a}}$ & $1.88^{\mathrm{b}}$ & $1.82^{\mathrm{b}}$ & $1.86^{\mathrm{b}}$ & $1.69^{\mathrm{b}}$ & 0.064 \\
\hline Intestinal villi height $(\mu \mathrm{m})^{\mathrm{ns}}$ & $14.55^{\mathrm{a}}$ & $12.76^{\mathrm{a}}$ & $11.84^{\mathrm{a}}$ & $14.77^{\mathrm{a}}$ & $13.25^{\mathrm{a}}$ & 0.550 \\
\hline
\end{tabular}

Means followed by different letters on the same line differ by Tukey's test $(\mathrm{p}<0.05)$.

${ }^{1}$ Standard error mean.

${ }^{\mathrm{ns}}$ Not significant.

$*$ Quadratic effect $\left(Y=-0.66 x^{2}+29.00 x+0.16 / R^{2}=0.85\right)$.

TABLE V

Body chemical composition of Nile tilapia fingerlings fed with increasing levels of inclusion of propolis extract in the diet.

\begin{tabular}{|c|c|c|c|c|c|c|}
\hline \multirow{2}{*}{ Parameters } & \multicolumn{5}{|c|}{ Levels of inclusion of dry propolis in the diet $(\mathrm{g} / \mathrm{kg})$} & \multirow{2}{*}{$\operatorname{SEM}^{1}(\%)$} \\
\hline & $\mathbf{0}$ & 1 & 2 & 3 & 4 & \\
\hline Ether extract $(\%)^{\text {ns }}$ & $10.49^{\mathrm{a}}$ & $10.28^{\mathrm{a}}$ & $11.38^{\mathrm{a}}$ & $11.72^{\mathrm{a}}$ & $11.62^{\mathrm{a}}$ & 0.298 \\
\hline Crude protein $(\%)^{*}$ & $20.48^{\mathrm{a}}$ & $24.03^{\mathrm{b}}$ & $24.01^{\mathrm{b}}$ & $24.43^{\mathrm{b}}$ & $24.12^{\mathrm{b}}$ & 0.737 \\
\hline Moisture (\%) ${ }^{\mathrm{ns}}$ & $74.50^{\mathrm{a}}$ & $74.66^{\mathrm{a}}$ & $75.05^{\mathrm{a}}$ & $74.99^{\mathrm{a}}$ & $76.36^{\mathrm{a}}$ & 0.328 \\
\hline Mineral matter $(\%)^{\mathrm{ns}}$ & $1.53^{\mathrm{a}}$ & $1.41^{\mathrm{a}}$ & $1.34^{\mathrm{a}}$ & $1.37^{\mathrm{a}}$ & $1.70^{\mathrm{a}}$ & 0.453 \\
\hline
\end{tabular}

Means followed by different letters on the same line differ by Tukey's test $(p<0.05)$.

${ }^{1}$ Standard error mean.

${ }^{\mathrm{ns}}$ Not significant.

*Quadratic effect $\left(y=-0.52 x^{2}+2.848 x+20.838 ; R^{2}=0.79\right)$.

composition variation, which is dependent on the resin collection period, the present flora ecological diversity, seasonality, and even the bees' genetic variability (Lustosa et al. 2008).

The data of the present study corroborate with those obtained by Uczay et al. (2014), who verified that the inclusion of $2 \mathrm{~g}$ of dry propolis $/ \mathrm{kg}$ of the diet, as propolis extract, for South American catfish (Rhamdia quelen) provided improvement in the condition factor. Also, Waafa et al. (2014) determined that $5 \mathrm{~g}$ of propolis extract resulted in improvement in the condition factor for Nile tilapia fingerlings. These results demonstrate the functional effects of propolis, since there was improvement of the condition factor that is widely used in fish biology as an indicator of good nutritional condition and fish health (Waafa et al. 2014, Vazzoler 1996). The condition factor is used to evaluate the different feeding conditions among the fish species, as well as the interference of population density, climate and other environmental conditions, and can provide a possible relation of the body condition and/or physiological state with the environment in that fish lives.

According to Gomiero and Braga (2003), the weight-length relationship can be used as a quantitative indicator of the welfare conditions of fish species in the environment, which is known as a condition factor. And although the present study did not evaluate fish welfare, the improvement in the condition factor, which by concept is an indicator of well-being, may indicate that fish 
treated with propolis are in better conditions, including, potentially, better welfare conditions than those not treated, but it is necessary to carry out specific welfare evaluation to confirm this concept in practice.

The condition factor is further understood as an indicator of the energetic reserves of the tissues, and as follows, there is the expectation that a fish with a better condition factor, presents higher growth rates, as well as a greater reproductive and survival potential when compared to an animal in condition factor relatively worse (Pope and Kruse 2001). An improvement in the body condition factor indicates that the fish treated with propolis extract may present better growth rates, survival, and higher reproductive potential, compared to untreated fish (Cho 2011).

The improvement in the condition factor of the Nile tilapias fed with propolis extract may have been an effect of the properties already confirmed of propolis for other species of fish, such antimicrobial, immunomodulatory and antioxidant (Soltani et al. 2017, Deng et al. 2011, Talas and Gulhan 2009). And, furthermore, De La CruzCervantes et al. (2018) stated that even at low doses propolis extract improves resistance to disease, and improving the health of some species of fish, in this way can be considered a functional natural additive.

In this study, no significant differences $(p>0.05)$ were observed in the effectiveness of sex reversal, particularly the alcoholic extract of propolis inclusion in the diet did not influence the hormone effectiveness. The success in the period of sex reversion depends exclusively on the animal's access to the masculinizing hormone, so the ideal would be the increase in the frequency of feeding, as it promotes a constant supply of hormone in the blood, causing this hormone to remain in the blood stream for longer (Meurer et al. 2012).

Post-larvae survival in this experiment was relatively low, although it was not influenced by the treatments. In this life stage several factors can influence, such as egg yolk quality, breeding nutritional status, storage density and manipulation for performance evaluation (Calado et al. 2008).

The morphological analysis of intestinal villi from the middle portion of the Nile tilapia postlarvae and fingerlings intestine presented normal organization of the intestinal tunics composed by the mucosa, the submucosa, the muscular and the serous layers (Figures 3 and 4), regardless of the inclusion level of the propolis extract. The mucosa layer presented simple columnar epithelium with normal goblet cells, the villi presented a leaf-shaped aspect and irregularities concerning its height, and the presence of intestinal crypts was not observed.

The characteristics morphological analysis of intestinal villi for Nile tilapia post-larvae and fingerlings fed with increasing levels of the propolis extract were normal for teleost fish in general (Takashima 1995) and also for the tilapias (Gargiulo et al. 1998). Oetting et al. (2006) suggested that plant extracts can improve the digestion of treated animals by stimulating the enzymatic activity of nitrogen absorption by changes in the intestinal epithelium histology. For terrestrial species, it has already been confirmed that the propolis extract has a positive effect on the immune system stimulating the lymphatic tissue in the digestive system and changing the intestinal microbiology, thus improving the intestinal health, digestion and absorption of the animals (Taheri et al. 2005, Denli et al. 2005). Meantime, our study did not confirm this hypothesis, since the alcoholic extract of propolis supply in diets to Nile tilapia postlarvae and fingerlings did not cause changes in the intestinal epithelium histology (Figures 3 and 4).

Although the only change in the body composition of Nile tilapia fingerlings fed with alcoholic extract of propolis has been the increase of crude protein levels, this is a great indicator of the productive improvement of these fish. Propolis supplementation also caused an increase of the 

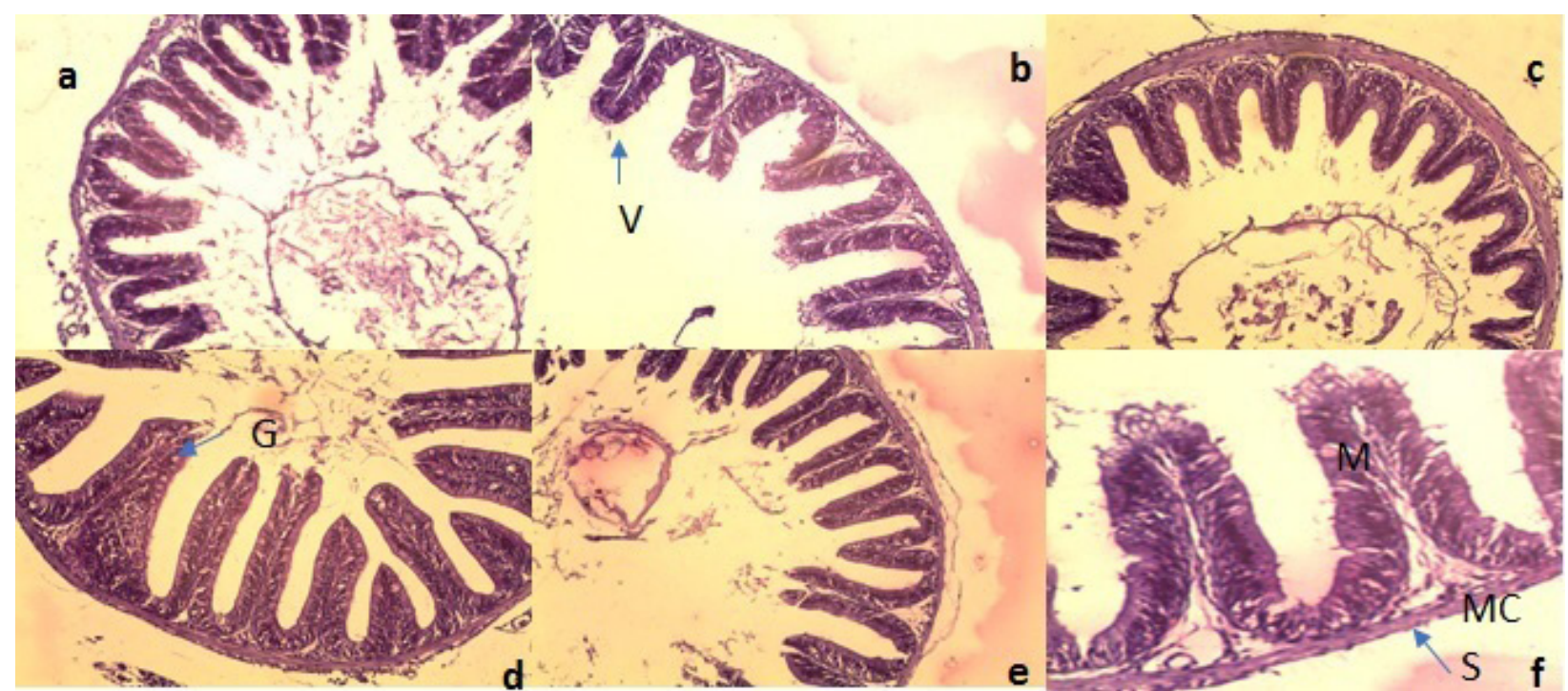

Figure 3 - Photomicrograph of the middle section intestinal of the Nile tilapia post-larvae supplemented with increasing levels of alcoholic extract of propolis. Treatment with $0 \mathrm{~g}$ of dry propolis $/ \mathrm{kg}=\mathbf{a} ; 1 \mathrm{~g} / \mathrm{kg}=\mathbf{b} ;$ observed villi (V); $2 \mathrm{~g} / \mathrm{kg}=\mathbf{c} ; 3 \mathrm{~g} / \mathrm{kg}=\mathbf{d}$, where goblet cell $(\mathrm{G})$ is observed; $4 \mathrm{~g} / \mathrm{kg}=\mathbf{e}$. In $\mathbf{f}$, is observed mucosa epithelium (M), muscular tunic (MC) and serous tunic (S). HE staining, 10X lens.
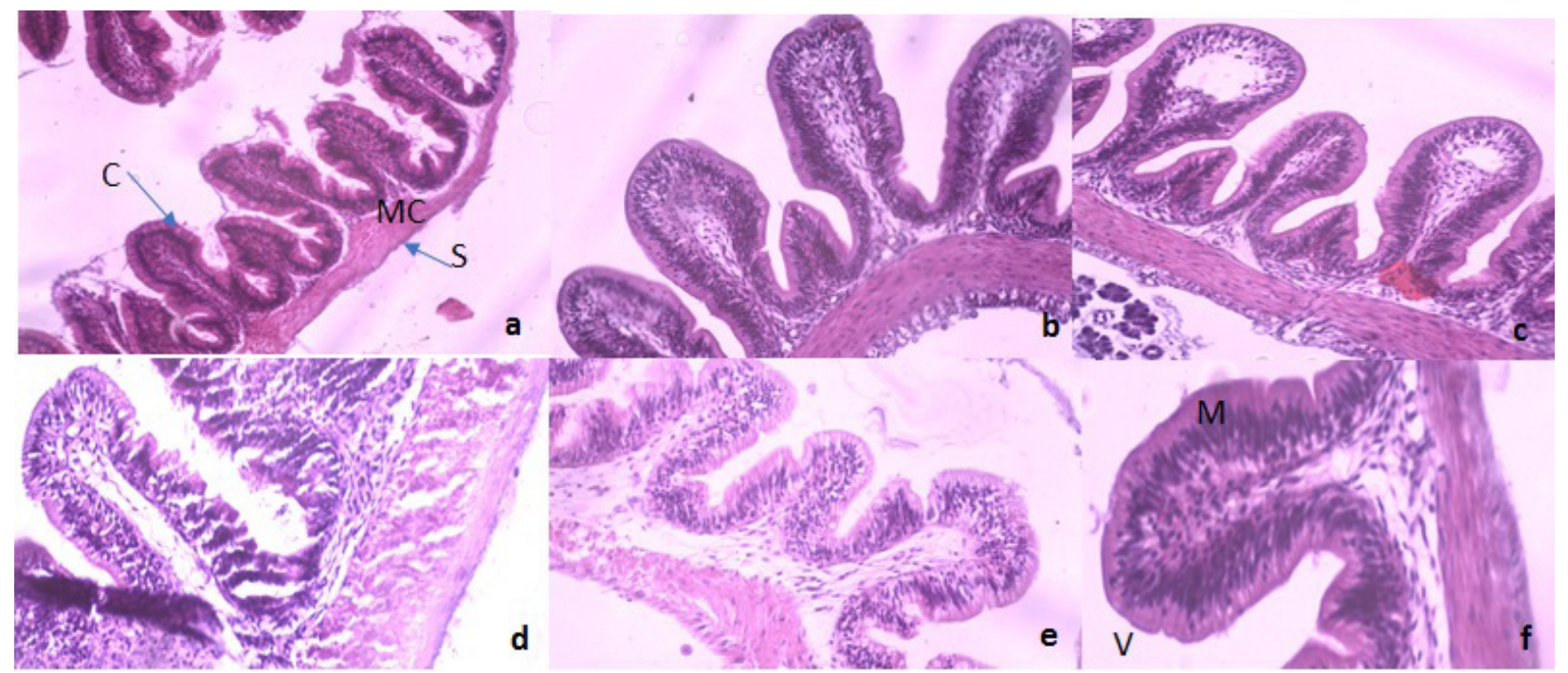

Figure 4 - Photomicrograph of the middle section intestinal of the Nile tilapia fingerlings supplemented with increasing levels of alcoholic extract of propolis. Treatment with $0 \mathrm{~g} / \mathrm{kg}=\mathbf{a}$, where goblet cell (C), muscular tunic (MC) and serous tunic (S) are observed; $1 \mathrm{~g} / \mathrm{kg}=\mathbf{b} ; 2 \mathrm{~g} / \mathrm{kg}=\mathbf{c} ; 3 \mathrm{~g} / \mathrm{kg}=\mathbf{d} ; 4 \mathrm{~g} / \mathrm{kg}=\mathbf{e}$. In f, is observed mucosa epithelium (M) and villi (V). HE staining, $10 X$ lens.

crude protein body to Nile tilapia fingerlings fed with $5 \mathrm{~g} / \mathrm{kg}$ of propolis extract in the feed (Waafa et al. 2014) and to juvenile eel fed with levels of 2.5 and $10 \mathrm{~g}$ of dry propolis/ $\mathrm{kg}$ in the diet (Bae et al. 2012). Nonetheless, these authors also verified an increase in moisture and mineral matter and lipid reduction with increasing levels of propolis $(5 \mathrm{~g} / \mathrm{kg}$ or up to $40 \mathrm{~g} / \mathrm{kg}$, respectively), which could not be observed in the present study (Waafa et al. 2014, Bae et al. 2012).

There was a great difference in the levels of propolis supplementation between the present study and those aforementionated, but in all cases an improvement in fish body composition could 
be observed. Meanwhile, this effect was not observed to juvenile rainbow trout (Oncorhynchus mykiss), for which alcoholic extract of propolis supplementation up to $4 \mathrm{~g} / \mathrm{kg}$ did not influence the body composition (Deng et al. 2011).

De La Cruz-Cervantes et al. (2018) mention that propolis extract leads to feed assimilation in fish. Bae et al. (2012) also suggested that some compounds present in propolis, such as flavonoids and phenolics, can improve the absorption and nutrients metabolism in fish. However, these active compounds have not been identified in the present study and should be the focus of future research for Nile tilapia.

The mechanism of propolis biological action is attributed to the interaction of its constituents (more than 300), among which flavonoids have been shown to be the major compounds and with the most important biological activity (Ferreira et al. 2017, Bankova et al. 1998). Nonetheless, the bioactive components present in the propolis are variable according to the collection site, seasonality, and method of preparation (Schnitzler et al. 2010, Silva et al. 2006).

The improvement in the condition factor, that is, in the fingerlings physiological state, may have influenced the greater deposition of body protein, since they assimilate the nutrients better. The increase in the animals' body protein represents a better quality of the fish and can lead to better productivity for fish farmers.

\section{CONCLUSION}

The alcoholic extract propolis inclusion from $1 \mathrm{~g} / \mathrm{kg}$ in the diet for post-larvae and fingerlings Nile tilapia, respectively, resulted in a better body condition factor and greater body protein deposition. The improvement in the body condition factor indicates that the propolis extract promotes better nutritional condition to the Nile tilapias in the early stages, which could potentially lead to better rates of growth and productivity, survival and reproduction in subsequent phases.

\section{ACKNOWLEDGMENTS}

The authors would like to thank the Fundação Araucária (Brazil) for financial support, under Grant nº 18887 - Convênio 465/2010 (UFPR).

\section{AUTHOR CONTRIBUTIONS}

This manuscript was developed and elaborated by Lilian Dena dos Santos, Izabel Volkweis Zadinelo, Lilian Carolina Rosa da Silva, Rogério Luiz Zilli, Marco Antonio Bacellar Barreiros, Marlise Teresinha Mauerwerk and Fábio Meurer, who are researches from interdisciplinary areas. The conceptual idea of using propolis as an additive in diets in the early stages of Nile tilapia was conceived by Lilian Dena dos Santos and Fabio Meurer, in addition to the design of the research. Fábio Meurer devised the experimental design and formulated diets. Izabel Volkweis Zadinelo, Augusto Moesch, Marlise Teresinha Mauerwerk and Rogério Luiz Zilli carried out the experiments, data collection and analysis of water physical and chemical variables. Lilian Dena dos Santos implemented the research, processed the experimental data, performed the centesimal composition analysis, drafted the manuscript and designed the figures. Lilian Carolina Rosa da Silva performed the histological analysis, hepatosomatic index and designed the figures. Lilian Dena dos Santos, Fábio Meurer, and Marco Antonio Bacellar Barreiros analyzed the data (statistically). Lilian Dena dos Santos supervised the project. All authors discussed the results and contributed to the final manuscript.

\section{REFERENCES}

ABDEL-MOHSEIN HS, MAHMOUD MAM AND MAHMOUD UT. 2014. Influence of propolis on intestinal 
microflora of ross broilers exposed to hot environment. Adv Anim Vet Sci 2: 204-211.

AOAC. 1995. Official methods of analysis. 16th ed., Washington (DC): Association of Official Analytical Chemists.

APHA. 2005. Standard methods for the examination of water and wastewater. $21^{\text {th }}$ ed., Washington (DC): American Public Health Association.

BAE JY, PARK GH, LEE JY, OKORIE OE AND BAI SC. 2012. Effects of dietary propolis supplementation on growth performance, immune responses, disease resistance and body composition of juvenile eel, Anguilla japonica. Aquac Int 20: 513-523.

BANKOVA V, BOUDOUROVA-KRASTEVA G, POPOV S, SFORCIN JM AND FUNARI RSC. 1998. Seasonal variations of the chemical composition of Brazilian propolis. Apidologie 29: 361-367.

CALADO LL, YASUI GS, RIBEIRO FILHO OP, SANTOS LC, SHIMODA E AND VIDAL JUNIOR MV. 2008. Densidades de incubação de ovos de tilápia do Nilo (Oreochromis niloticus) em sistema alternativo. Cienc Animal 18: 75-80.

CHO SH. 2011. Effects of Putative Growth or HealthEnhancing Dietary Additives on Juvenile Olive Flounder, Paralichthys olivaceus, Performance. J World Aquac Soc 42: 90-95.

COELHO MS, SILVA JHV, OLIVEIRA ERA, AMÂNCIO ALL, SILVA NV AND LIMA RMB. 2010. Propolis and its use in production animals. Arch Zootec 59: 95-112.

CONCEA. 2018. Resolução normativa $n^{\circ} 37$, de 15 de fevereiro de 2018. Diretriz da Prática de Eutanásia do Conselho Nacional de Controle de Experimentação Animal - Concea. Brasília, DF.

CYRINO JEP, BICUDO AJA, SADO RY, BORGHESI R AND DAIRIKI JK. 2010. Fish farming and the environment the use of environmental friendly feeds in fish culture. $\mathrm{R}$ Bras Zootec 39: 68-87.

DE LA CRUZ-CERVANTES JA, BENAVIDES-GONZALEZ F, SANCHEZ-MARTINEZ JG, VAZQUEZ-SAUCEDA MLL AND RUIZ-URIBE AJ. 2018. Propolis in Aquaculture: A Review of Its Potential. Rev Fish Sci \& Aquac 26: 337-349.

DENG J, AN Q, BI B, WANG Q, KONG L, TAO L AND ZHANG X. 2011. Effect of ethanolic extract of propolis on growth performance and plasma biochemical parameters of rainbow trout (Oncorhynchus mykiss). Fish Physiol Biochem 37: 959-967.

DENLIM, CANKAYAS, SILICIS, OKANFANDULUOCAK AN. 2005. Effect of dietary addition of Turkish propolis on the growth performance, carcass characteristics and serum variables of Quail (Coturnix coturnix japonica). AsianAust J Anim Sci 18: 848-854.
FERREIRA JM, FERNANDES-SILVA CC, SALATINO A, NEGRI G AND MESSAGE D. 2017. New propolis type from north-east Brazil: chemical composition, antioxidant activity and botanical origin. J Sci Food Agric 97: 35523558 .

GARGIULO AM, CECCARELLI P, DALL'AGLIO C AND PEDINI V. 1998. Histology and ultrastructure of the gut of the tilapia (Tilapia spp.), a hybrid teleost. Anat Histol Embryol 27: 89-94.

GOMIERO LM AND BRAGA FMS. 2003. Relação pesocomprimento e fator de condição para Cichla cf. ocellaris e Cichla monoculus (Perciformes, Cichlidae) no reservatório de Volta Grande, rio Grande - MG/SP. Acta Sci Biol Sci 25: 79-86.

GONZALES E, MELLO HHC AND CAFÉ MB. 2012. Uso de antibióticos promotores de crescimento na alimentação e produção animal. Rev UFG 13: 49-52.

HAYASHI C, BOSCOLO WR, SOARES CM AND MEURER F. 2002. Exigência de proteína digestível para larvas de tilápia do Nilo (Oreochromis niloticus) durante a reversão sexual. Rev Bras Zootec 31: 823-828.

LUSTOSA SR, GALINDO AB, NUNES LCC, RANDAU KP AND ROLIM NETO PJ. 2008. Propolis: updates on chemistry and pharmacology. Rev Bras Farmacogn 18(3): 447-454.

MARENGONI NG AND WILD MB. 2014. Sistemas de produção de pós-larvas de tilápia do Nilo. Sci Agrar Paran 13: 265-276.

MEURER F, BOMBARDELLI RA, PAIXÃO PS, SILVA LCR AND SANTOS LD. 2012. Feeding frequency on growth and male percentage during sexual reversion phase of Nile tilapia. Rev Bras Saúde Prod Animal 13: 1133-1142.

MEURER F, COSTA MM, BARROS DAD, OLIVEIRA STL AND PAIXÃO PS. 2009. Brown propolis extract in feed as a growth promoter of Nile tilapia (Oreochromis niloticus) fingerlings. Aquac Res 40: 603-608.

NRC. 2011. Nutrient Requirements of Fish and Shrimp. Washington (DC): The National Academies Press: National Research Council.

OETTING LL, UTIYAMA CE, GIANI PA, RUIZ US AND MYIADA VS. 2006. Efeitos de extratos vegetais e antimicrobianos sobre a digestibilidade aparente, o desempenho, a morfometria dos órgãos e a histologia intestinal de leitões recém-desmamados. Rev Bras Zootec 35: 1389-1397.

PEZZATO LE, MIRANDA EC, BARROS MM, PINTO LGQ, FURUYA WM AND PEZZATO AC. 2002. Digestibilidade aparente de ingredientes pela tilápia do Nilo (Oreochromis niloticus). Rev Bras Zootec 31: 1595-1604.

POPE KL AND KRUSE CG. 2001. Assessment of fish condition data. In: Guy C and Brown M (Eds), Statistical Analyses of Freshwater Fisheries Data. North Bethesda: American Fisheries Society, p. 51-56. 
POPMA TJ AND GREEN BW. 1990. Sex reversal of tilapia in earth ponds - Aquaculture production manual. Research and Development Series n ${ }^{\circ}$ 35. Alabama: Auburn University, $15 \mathrm{p}$.

SANTOS EL, SILVA FSB, PONTES EC, LIRA RC AND CAVALCANTI MCA. 2013. Residue of the process red propolis extract in commercial ration on performance of Nile tilapia fingerlings (Oreochromis niloticus). Com Sci 4: $179-185$.

SCHNITZLER P, NEUNER A, NOLKEMPER S, ZUNDEL C, NOWACK H, SENSCH KH AND REICHLING J. 2010. Antiviral activity and mode of action of propolis extracts and selected compounds. Phytother Res 24: S20-S28.

SILVA RA, RODRIGUES AE, RIBEIRO MCM, CUSTÓDIO, AR, ANDRADE NED AND PEREIRA WE. 2006. Características físico-químicas e atividade antimicrobiana de extratos de própolis da Paraíba, Brasil. Cienc Rural 36: 1842-1848.

SIMÕES LN, PAIVA G AND GOMES LC. 2010. Óleo de cravo como anestésico em adultos de tilápia do Nilo. Pesq Agropec Bras 45: 1472-1477.

SOLTANI EK, CEREZUELA R, CHAREF N, MEZAACHEAICHOUR S, ESTEBAN MA AND ZERROUG MM. 2017. Algerian propolis extracts: Chemical composition, bactericidal activity and in vitro effects on gilthead seabream innate immune responses. Fish Shellfish Immunol 62: 57-67.
STATSOFT, INC. 2004. STATISTICA (data analysis software system), version 7.

TAHERI HR, RAHMANI HR AND POURREZA J. 2005. Humoral immunity of broilers is affected by oil extracted propolis (OEP) in the diet. Intl J Poult Sci 4: 414-417.

TAKASHIMA F. 1995. An atlas of fish histology-normal and pathological features. $2^{\text {nd }}$ ed., Tokyo: Kondansha Ltda, 147 p.

TALAS ZS AND GULHAN MF. 2009. Effects of various propolis concentrations on biochemical and hematological parameters of rainbow trout (Oncorhynchus mykiss). Ecotoxicol Environ Saf 72(7): 1994-1998.

UCZAY J, LAZZARI R, PIANESSO D, ADORIAN TJ, MOMBACH PI AND DECARLI JA. 2011. Evaluación del propóleo como promotor de crescimento em la carpa comúm (Cyprinus carpio). Rev Cient XXI: 408-413.

UCZAY J, PIANESSO D, ADORIAN TJ, MOMBACH PT, COLDEBELLA IJ AND LAZZARI R. 2014. Propolis in diets for silver catfish (Teleostei, Pimelodidae). Biosci J 30: 1912-1918.

VAZZOLER AEAM. 1996. Biologia da reprodução de peixes teleósteos: teoria e prática. Maringá: EDUEM, 169 p.

WAFAA E, DOAA I, EL-MURR A AND RANIA M. 2014. Effects of dietary inclusion of black cumin seeds, green tea and propolis extraction on growth parameters, body composition and economic efficiency of Nile tilapia, Oreochromis niloticus. World J Fish Mar Sci 6(5): 447452. 